\title{
A State-of-the-Art Review on Action Learning Theory and Models for Organizational Development
}

\author{
KHUDA BAKHSH $^{1 *}$ MUHAMMAD HAFEEZ ${ }^{2}$, IFFAT BASIT ${ }^{3}$ \\ ${ }^{1 *}$ Department of Education, GC University Faisalabad, PAKISTAN. \\ ${ }^{2}$ Research Scholar, Allama Iqbal Open University, Islamabad, PAKISTAN. \\ ${ }^{3}$ Department of Education, Alhamd Islamic University, Islamabad, PAKISTAN.
}

\begin{abstract}
Action learning may be defined as a process supported by a collection of individuals that inductee imaginative resolutions to handle multiple difficulties. Action learning is an effective strategy to develop the management skills for organizations or indiviuals. It measures mainly team strategies in solving real life problem and supports the team building within an organization or company. Many effective organizations utilize action learning to understand workforce progress and development. The purpose of this article was to present a systematic and state of the art review of literature about action learning theory and models used for organizational development. A total 29 articles were selected from various data based by introducing the inclusion and exclusion criteria. The review of literature indicated that application of action learning theory improves the capacity building, self-efficacy and performance of the organizations. The review of literature also showed that by following action learning theory, an organization developed and progress rapidly. Some action learning models, principles, their limitations and outcomes are also discussed in this article. To strengthen the review results of development of organizations, a number of case studies were also presented in this review article to provide the evidences of action learning theory to improve the efficiency of organizations.
\end{abstract}

Keywords: Environment, Development, Action Learning Theory, Action Learning Models, Organizational Development, Case Studies

Received: May 31, 2021. Revised: September 14, 2021. Accepted: September 30, 2021. Published: October 14,2021

\section{Introduction}

Strong management abilities at all working levels have long been considered essential to improving an organization's performance. Effective management and strong leadership go hand in hand with well working services, dynamic and efficient staff. Action Learning is a strategy that can be utilized to discourse the encounter for improving the efficiency management [1]. This approach is wellestablished and has been widely employed in a variety of fields [2]. Action Learning is a longterm process focused on participation, getting knowledge and group reproduction. A set of peers meets on regular basis under the supervision of a qualified moderator. Members bring real-world problems into the debate with the goal of developing new and useful answers to complicated challenges and be implemented [3]. The meetings are done in a Socratic way, with participants discussing their concerns in a continuous question-and-answer format that encourages critical thinking and conversation while also clarifying preconceptions [4].
When neonle learn hands-on. thev learn more and hetter than when thev nassivelv ahsorh knowledge. I earning hv doing has heen proved to be an active approach of building management skills, particularly for senior administrators in industrialized states [5-6]. Action learning techniques have been employed in a variety of classes, especially to build advanced managerial skills and abilities [7]. The action learning theory demonstrated the improvement in self-confidence, conflict resolution, teamwork skills, self-efficacy, problem-solving skills, leadership skills and critical thinking skills in numerous organizations of the globe. All of these abilities are crucial for managers in general, but they are especially important for those who work in high-stress areas like neonatal units [8]. Action learning theory is followed in a small-group that allows team members to solve real-world problems in real time while also learning about the organisation as a dynamic and dynamic system between problem-solving and decision-making groups in which they participate. As, team members have a thorough comprehension of behavioural 
learning theory and are familiar with its research and reflection processes, they consistently put their new findings and knowledge to action [9].

\subsection{Purpose of the Study}

Action learning is a procedure of problems solving and play a significant role in organizational development. It can reflect the consequences of actions. Action learning theory not only improves the troubleshooting process, but also helps simplify teamdeveloped solutions [10-12]. By applying action learning process, the organizational system can be improved and modified. The main reason for conducting this study was to explore some evidence based literature for action learning theory, models and application of both for organizational development. A very rare studies were found in the literature that discussed the action learning theory and its usage in organizational development. The objectives of the current study were (i) to present a comprehensive and state of the art review on application of action learning theory for organizational development (ii) to present some action learning models used in action learning to improve the efficiency of organizations (iii) Challenges and their possible solutions in using action learning theory for organizational development.

\section{Methodology}

\section{Article Selection Process}

The key objective of current review research was to reveal the effectiveness of action learning theory and models for organizational development. For this purpose, Web of Science and Scopus database were selected to collect the review of related articles. In Web of Science and Scopus interface, "Action Learning Theory", "Models" and " Organizational Development" terms were entered as the main contents of the search. The custom year range from 2000 to June 2021" was determined as the time limit for current study. The advanced search was done from $5^{\text {th }}$ to $10^{\text {th }}$ august, 2021. Based on the initial results, 132 papers were discovered. The specific inclusion criteria was applied to limit articles for state of the art review on the effectiveness of action learning theory and models for organizational development. The first criterion was to use "Educational research" as a web of science and Scopus category. "Only items" as documents and Pdf types were the other inclusion criterion. After applying the inclusion criteria, 56 articles have been found. In order to conclude the research and review articles to be reviewed, specific exclusion criteria were then implemented. The first criterion of exclusion was to exclude more than once the same articles. Secondly, articles not available in full text were to be excluded. The final criterion for exclusion included the removal of articles that had no direct connection with the effectiveness of action learning theory and models for organizational development Finally, the main sample of this systemic review study was determined by a total of 29 articles. The main selection process is summarized in Figure 1. 


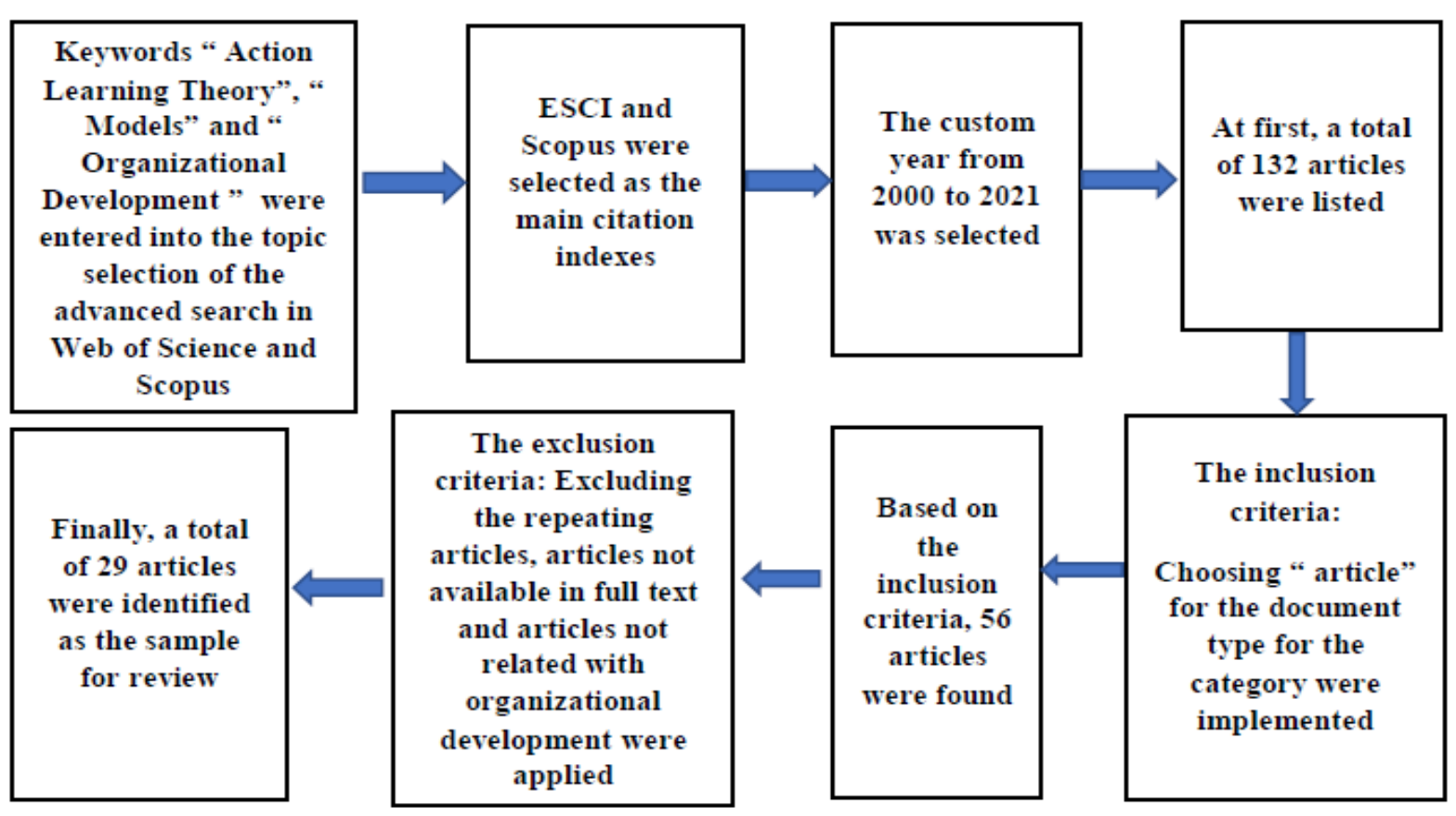

Figure 1. Article Selection Process

\section{Review of Relevant Literature}

\subsection{Concept of Action Learning}

Action learning may be defined as the process of creating reasonable answers for difficult challenges faced by individuals and organizations. It entails taking steps to remedy the problem and then assessing their effectiveness [13]. At all levels, action learning is an effective way of development. It is realized to be particularly suitable for collaborative problem-solving techniques and contributes to organisational team building [14]. The organizations that encourage staff development while also taking care to facilitate action learning get the rewards of a more competent and active staff. Numerous successful firms used action learning to enhance their personnel [15-16]. The founder of action learning theory, Professor Reginald Revans [17], discovered that allowing a small group of individuals to share their experiences and difficulties in order to find answers is an effective way to learn and solve problems.

\subsection{How Does Action Learning Work?}

The primary goal of action learning is to empower individuals and provide them with the opportunity to speak openly about the issues they face at their own level. The ideal method to continue this process is to gather a group of 6 to 8 like-minded people and set aside time for them to meet and discuss [18]. The working principle of action learning theory is shown in figure 2 .
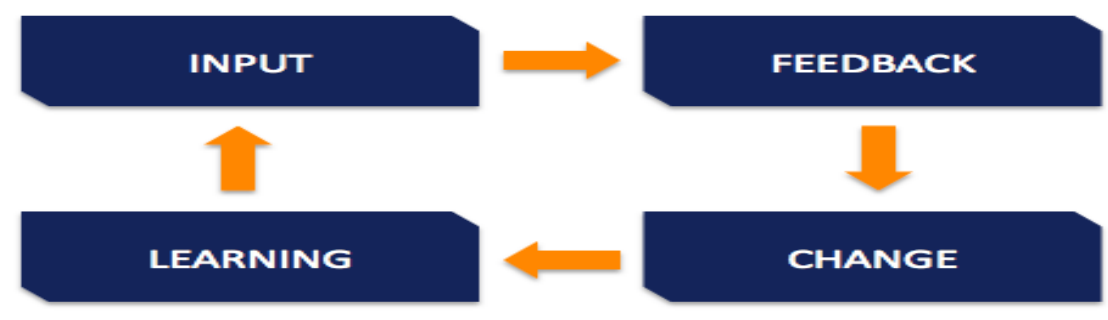

Figure 2. Working Principal of Action Learning Theory 
Action learning is a dynamic technique for resolving corporate problems, improving personal skills, forming teams, and developing leadership [19]. This is an efficient method for fostering mutual respect in a company as this technique guides people to keep asking questions and create developmental environment. It creates an environment in which a constant process of adaptability can take place [20].

\subsection{Steps in Action Learning to Solve the Problem}

\section{(i) Identification of Problem}

In around two minutes, the action learning coach will ask a participant to identify the concerns that the group should consider. The team members, as well as the ones who asked the questions, began to ask each other questions at this point. In addition, the moderator posed questions to the participants. When a question is posed, the seeds of a solution are sown, and the problem is then solved. In action learning, the team approaches the problem in a radically different way than the firm would normally approach the difficulty. Because they clearly identify the real problem before attempting to define the solution, action learning teams are able to come up with novel solutions [21-22].

\section{(ii) Problem Solving}

Before moving on to the solution phases, coaches play a vital role in validating the group's consensus on what the problem is. When the conversation shifts from problem analysis to solution, the coach recognises it and takes action [23-24]. When a coach demonstrates that the group is making an early transition from problem analysis to solution decision, intervention is required. The coach invites each individual to write down their knowledge of the situation during this intervention. Members will read what they have written aloud once they have written down their ideas about the topic. Writing and reading questions challenges the team to explore the true nature of the situation at hand, contrary to what each member believes. Participants admitted to see aspects of the situation they had never observed before when they listened to what others thought was a problem. This procedure can be frustrating for first-time active learners who are used to entering into solution mode. They soon realized that as they were evaluating the troubling scenario, they were also sowing the seeds for the following step and formulating solutions. This activity allows participants to quickly identify additional possibilities, regardless of how confident they are about the nature of the problem before they attend the problem-solving session [25-26].

\section{(iii) Time Management}

The intensity of action learning courses is high. When planning sessions, keep this in mind. Each lesson should not last more than four hours per day and the time between classes should not be more than four weeks. The meetings that have been going on for several days have produced shocking outcomes. Similar tendencies are frequently seen in action learning groups. The process began slowly, with participants having trouble asking inquiries [27]. The process began to quicken after the initial intervention; the coach drew all participants into the dialogue and assisted them in figuring out how to communicate more effectively. In addition to assisting them in determining how to ask better questions and collaborate more effectively, coaches also conduct research to ensure that members know why certain actions are most effective. A particularly exciting meeting took place when the party was reunited after a night's rest. Subconscious: Working all night on learning and problems, when the team meets again in the morning, it will produce a strong spark. This new relationship between group members permeates their daily activities from that moment; the dialogue changes from a statement to a problem, because the people involved in action learning realize that the real power lies in identifying the unknown, rather than showing the known [28-29].

\section{(iv) Session of Questioning and their Answering}

The coach inquiries about learning possibilities during the question. They come in a variety of shapes and sizes. Early intervention, which occurs within the first 10 minutes of the session, is the easiest opportunity. The goal is to ensure that the group starts with a team, but it's also critical 
that everyone participates. Coaches are also looking for the following opportunities:

- Reinforcing when all the things are going well

- Helping teams achieve better results

Each time the coach guides the test group to explore more deeply how the group feels. Through this process, the team discovers and visualizes problems lurking under the table. This will release the tension in the air, allow the group to become a better team and focus on solving the major problems in front of you. If the team coach does not identify an observed learning opportunity, the coach uses future positive questions to recognize it. The last question at the coach leads the team as they decide how to move forward [30].

\section{(v) Resolution}

For the course of the project, team members are urged to keep a learning journal. They don't expect you to share what they write with others. Rather, they are required to summarize their learning journey at the end of the endeavour. The team learning journey's composition should be provided at the start of the final presentation to the $\mathrm{C}$ suite (executivelevel managers within a company). A project's outcome can be dramatic. In an ideal scenario, having a team behind you allows you to implement a solution sooner rather than later. Unfortunately, in the actual world, it isn't trustworthy enough. $\mathrm{C}$ suite generally requires a presentation of the problem and solution. Therefore, the team will continue to work with the owner of the problem. The team will periodically notify the owner of the issue of progress. These meetings can review the scope, see if the path the team is taking is acceptable by $\mathrm{C}$ suite (management level manager within the company), and handle any issues that arise. When it comes to the date of the presentation, the owner or team in question should not be surprised. The expected response of the presentation was that all systems disappeared. The unimplemented solution often results in team atrophy, causing processes to fail, making sessions impossible to perform future actions [31].

\subsection{Integration of Models in Action Learning}

\section{(i) Action Learning Group Process Model}

Gregory's [32] Action Learning Group Process Model includes action learning and action research into the Talent Strategies Graduate Program's management development process. This paradigm contains four phases, which are followed by scientific investigations to keep looking at difficulties. Gregory's [32] concept was based on Lewin, [33] and Kolb's [34] experiential learning model. This is due to the fact that this model is built on the same assumptions as Revans' [17] theory of behavioural learning. Furthermore, the experiential learning paradigm was founded on research. Gregory, [32] believed that scientific research is the greatest research approach for graduate programmes and that taking responsibility for one's actions motivates human resource professionals to develop. It is shown in figure 3. 


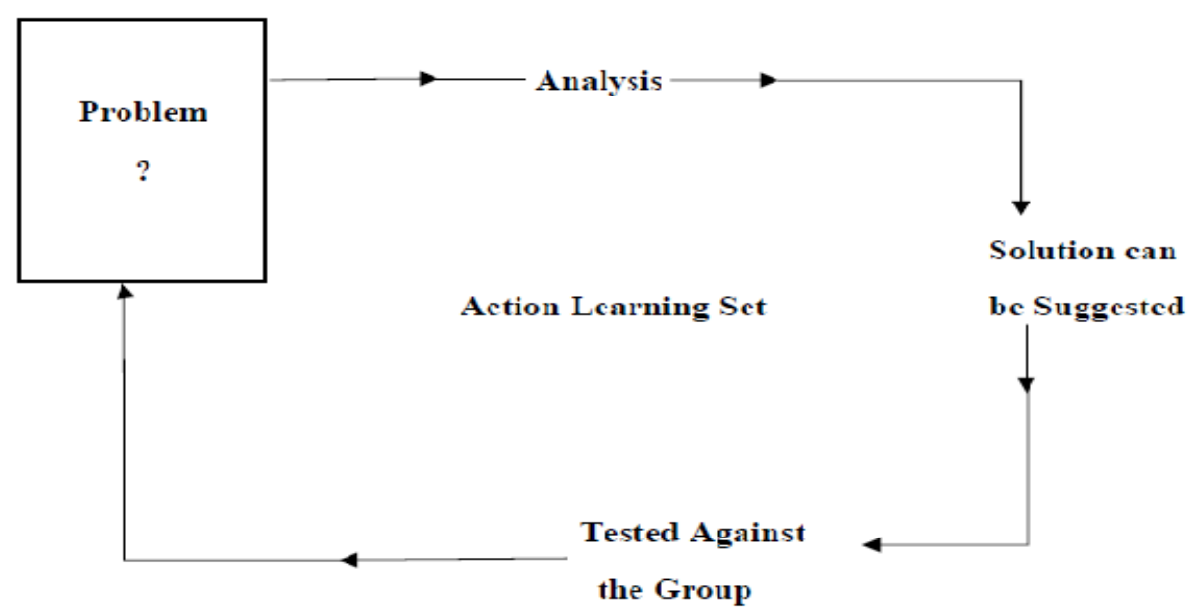

Figure 3. Schematic of Action Learning Group Process Model

ii) Systemic Action Learning Cycle (SALC) Model

The four phases of Paton's Systemic Action Learning Cycle cited by Paton [33], was based on Critical Systems Theory. The reiterative aspect of analyzing organisational issues as part of a behaviour learning cycle is emphasised by the theory of built-in key schemes. Because there is no metamethodological state bluff in the SALC model, it can be used with a variety of techniques [35]. The model is made up of the steps as (i) Alert (ii) Comprehend (iii) Consider (iv) Compare (v) Act. The learning process in Systemic Action Learning Cycle (SALC) model is shown in figure 4.

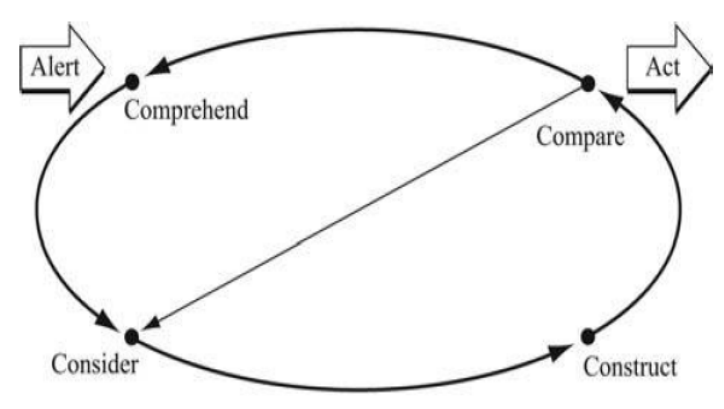

Figure 4. Learning in Systemic Action Learning Cycle (SALC) Model 


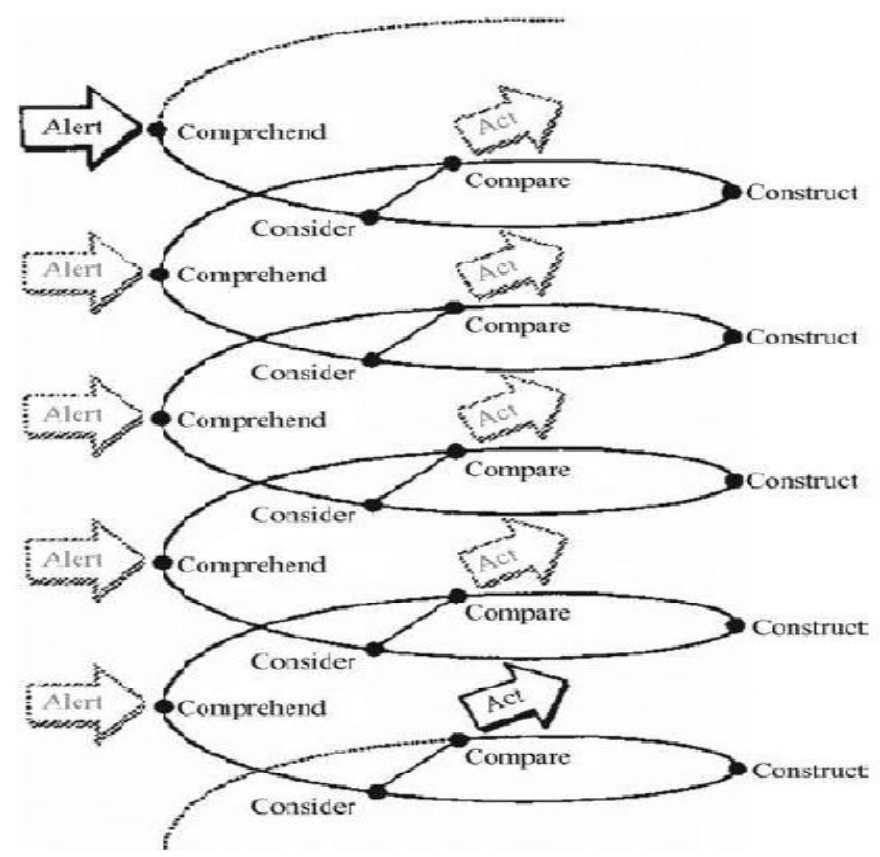

Figure. 5: Schematic of Systematic Action Learning Spiral

(iii)

\section{Systemic Action Learning Spiral Model}

This model was developed using critical systems theory, which integrates single, double and triple loop learning theories to determine the level of study that may occur when using action learning theory to investigate organizational difficulties and problems $[33,36]$. The schematic of systematic action learning spiral is shown in figure 5 .

\section{(iv) Continuous Action Learning Model}

Argyris' theories of action learning are incorporated into Watkins \& Marsick' [36] perspectives of organisational learning. Their unique concept of continuous learning is built on a practical, operational method for problem-solving in rea and day-to-day scenarios. Reflecting on the nature of the issue and applying the problem-solving method referred to by Argyris and Schon as single loop learning can lead to a level of learning [37]. The schematic diagram of continuous action

learning

model is shown in figure 6 .

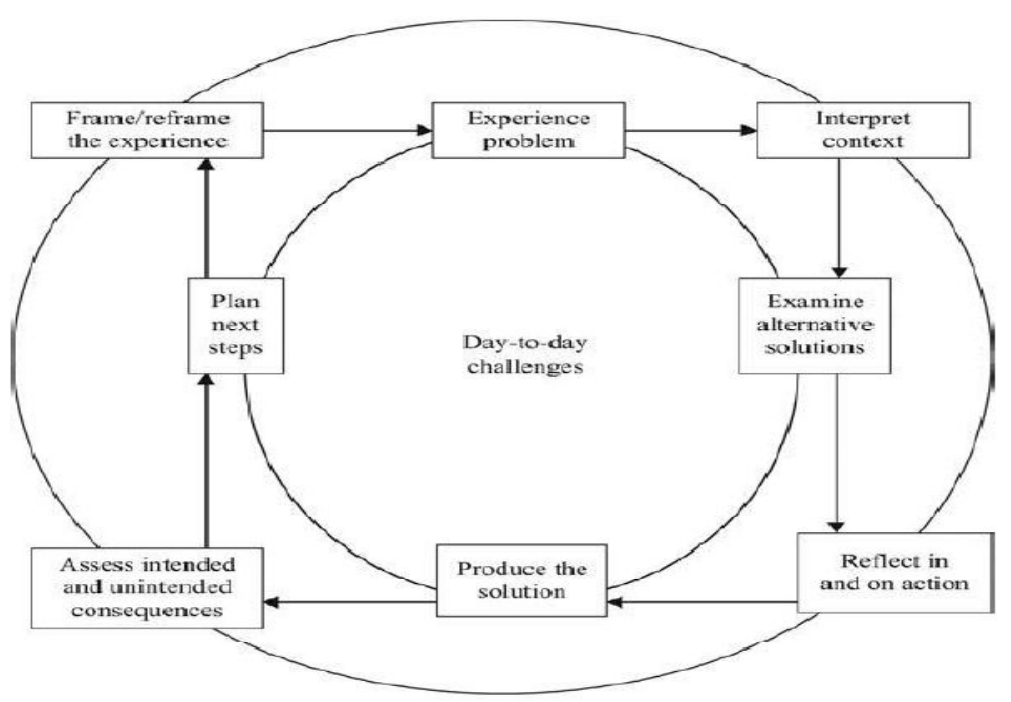


Table.1: Action Learning Models, their Working Principles, Outcomes, Limitations and Strength

\begin{tabular}{|c|c|c|c|c|c|}
\hline Model Name & Author & Definition & Working Principle & $\begin{array}{l}\text { Expected } \\
\text { Outcomes } \\
\end{array}$ & Strengths and Limitations \\
\hline $\begin{array}{l}\text { Action Learning } \\
\text { Group Process } \\
\text { Model }\end{array}$ & $\begin{array}{l}\text { Gregory } \\
{[32]}\end{array}$ & $\begin{array}{l}\text { Implements } \\
\text { management } \\
\text { development action } \\
\text { learning and action } \\
\text { research }\end{array}$ & $\begin{array}{l}\text { The key attention of the } \\
\text { learning experience is to } \\
\text { discover a solution to a } \\
\text { problem in the real world. } \\
\text { Learning is a volunteer } \\
\text { process and the student must } \\
\text { be ready to learn. } \\
\text { Action Learning is a highly } \\
\text { social process and activity that } \\
\text { requires time to be completely } \\
\text { efficient. } \\
\text { The standard programme of } \\
\text { action learning may span from } \\
\text { four to nine months. }\end{array}$ & $\begin{array}{l}\text { The ability of } \\
\text { staff to influence } \\
\text { strategic decision } \\
\text { making }\end{array}$ & $\begin{array}{l}\text { Women and men only learn } \\
\text { when they desire to learn. } \\
\text { One key motivation to desire } \\
\text { to learn is to know that you } \\
\text { are not able to accomplish } \\
\text { your work well. } \\
\text { Learning is a social process, } \\
\text { as learners work together to } \\
\text { help each other with certain } \\
\text { challenges of mutual interest. }\end{array}$ \\
\hline $\begin{array}{l}\text { Systemic Action } \\
\text { Learning Cycle } \\
\text { (SALC) }\end{array}$ & $\begin{array}{l}\text { Paton, } \\
\text { [33] }\end{array}$ & $\begin{array}{l}\text { In most approaches an } \\
\text { activity cycle has been } \\
\text { encapsulated that leads } \\
\text { from a first alarm event } \\
\text { to a thought process. }\end{array}$ & $\begin{array}{l}\text { Alert: The act of initiating the } \\
\text { inquiry. } \\
\text { Comprehend: This is a set of } \\
\text { activities, or more accurately, } \\
\text { by which an analyst gains a } \\
\text { knowledge of the issue. } \\
\text { Consider: This is the act of } \\
\text { planning the specific } \\
\text { (systemic) modeling to be } \\
\text { undertaken in this analysis. } \\
\text { Compare: In this act the } \\
\text { models created are compared } \\
\text { with what is known about the } \\
\text { situation in order to facilitate } \\
\text { some end-activity to this cycle } \\
\text { of analysis. } \\
\text { Act: This culminates the cycle } \\
\text { by carrying out the planned } \\
\text { end-activity arising from the } \\
\text { comparison. }\end{array}$ & $\begin{array}{l}\text { By guiding the } \\
\text { decision-making } \\
\text { process using the } \\
\text { generic learning } \\
\text { action phases, you } \\
\text { can accomplish } \\
\text { the intended } \\
\text { results by taking } \\
\text { suitable measures } \\
\text { to address an } \\
\text { issue. }\end{array}$ & $\begin{array}{l}\text { In contrast to similar form } \\
\text { models that were intended } \\
\text { for certain techniques, } \\
\text { several methodologies could } \\
\text { be used to this model. } \\
\text { In relation to the use of } \\
\text { relevant situational models } \\
\text { together with the SALC } \\
\text { model during analysis, Paton } \\
\text { explained the flexibility of } \\
\text { the SALC model. }\end{array}$ \\
\hline $\begin{array}{l}\text { Systemic action } \\
\text { learning spiral } \\
\text { model }\end{array}$ & $\begin{array}{l}\text { Paton, } \\
{[33]}\end{array}$ & $\begin{array}{l}\text { This model shows how a } \\
\text { range of analytical } \\
\text { cycles for systemic } \\
\text { problem resolution } \\
\text { might spiral over time. }\end{array}$ & $\begin{array}{l}\text { Cyclical approach of learning } \\
\text { Deepen every irregularity } \\
\text { Learning via Previous } \\
\text { Knowledge }\end{array}$ & $\begin{array}{l}\text { This model } \\
\text { reflects the } \\
\text { process of } \\
\text { analyzing } \\
\text { iteratively but the } \\
\text { results of action } \\
\text { learning are } \\
\text { unspecified and } \\
\text { predictable. }\end{array}$ & $\begin{array}{l}\text { One of its main features is } \\
\text { that it is versatile and may be } \\
\text { employed with a number of } \\
\text { quantitative or qualitative } \\
\text { research approaches or both } \\
\text { in a variety of environments. } \\
\text { A first limitation is that "by } \\
\text { focusing on methodologies, } \\
\text { the approach preserves the } \\
\text { need for the practitioner to } \\
\text { have a command of a range } \\
\text { of methodologies to be } \\
\text { effective" } \\
\text { Secondly, cyclic diagrams } \\
\text { are misleading as } \\
\text { diagrammatical captures } \\
\text { cannot effectively represent } \\
\text { the iterative, interrelated and } \\
\text { holistic structure of systems } \\
\text { of thinking. }\end{array}$ \\
\hline $\begin{array}{l}\text { Continuous } \\
\text { Learning Model }\end{array}$ & $\begin{array}{l}\text { Watkins } \\
\& \\
\text { Marsick, } \\
{[36]}\end{array}$ & $\begin{array}{l}\text { The inner circle is the } \\
\text { simple steps in the } \\
\text { solution cycle. } \\
\text { The external circle of } \\
\text { the model reflects the }\end{array}$ & $\begin{array}{l}\text { Leaders start to learn } \\
\text { continuously } \\
\text { Create a curriculum }\end{array}$ & $\begin{array}{l}\text { The resolution of } \\
\text { everyday } \\
\text { difficulties and } \\
\text { the prevention of }\end{array}$ & $\begin{array}{l}\text { A focus on everyday } \\
\text { difficulties and problem- } \\
\text { solving orientation are the } \\
\text { obvious characteristics of }\end{array}$ \\
\hline
\end{tabular}




\begin{tabular}{|c|c|c|c|c|c|}
\hline & & $\begin{array}{l}\text { deeper level of } \\
\text { knowledge that can be } \\
\text { achieved by critically } \\
\text { thinking on the } \\
\text { underlying premises of } \\
\text { understanding and } \\
\text { conviction. }\end{array}$ & $\begin{array}{l}\text { Provide the materials and time } \\
\text { to learn continuously }\end{array}$ & $\begin{array}{l}\text { future recurrence } \\
\text { by critical } \\
\text { reflection of these } \\
\text { situations. }\end{array}$ & $\begin{array}{l}\text { this methodology. The model } \\
\text { is an intrinsic practical } \\
\text { model with these major } \\
\text { qualities and results. } \\
\text { The concept for practical } \\
\text { managers and consultants } \\
\text { can be used fast and easily. } \\
\text { These strengths can also be } \\
\text { seen as restrictions. }\end{array}$ \\
\hline
\end{tabular}

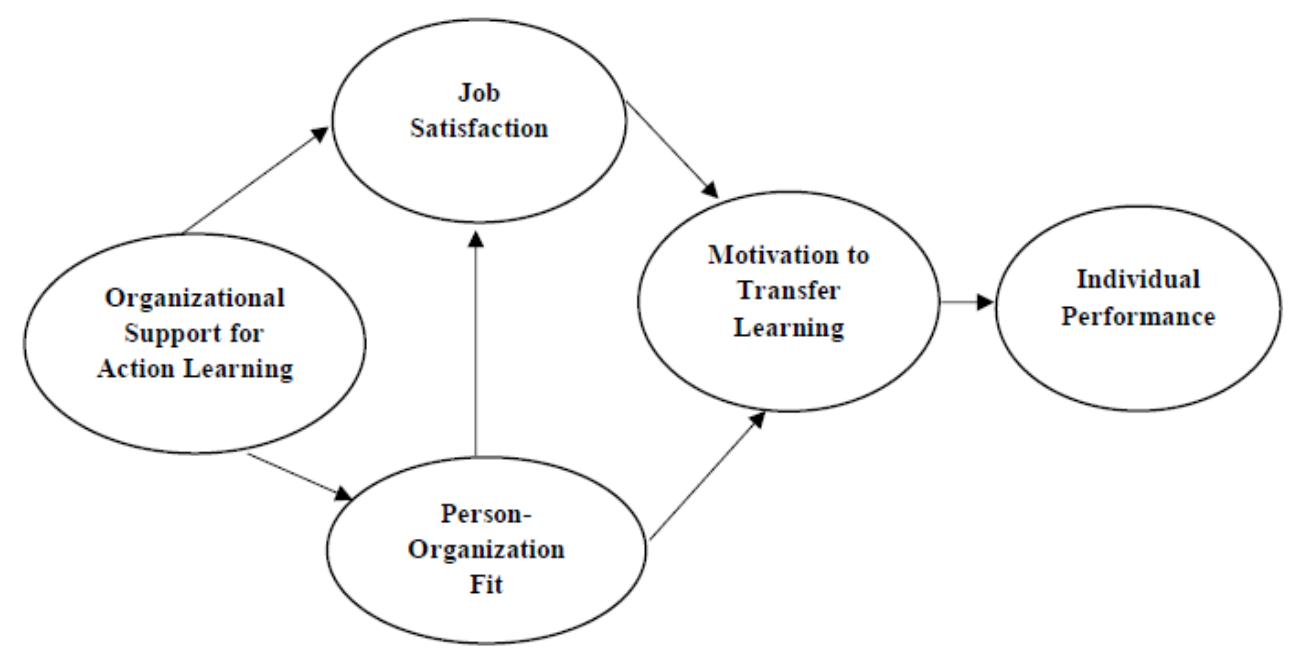

Figure 7. Process for Organizational Support in Action Learning

\subsection{Action Learning Theory in Organizational Development}

Action learning (AL) is a method that allows individuals or groups to acquire while solving issues and carrying out actions. AL has increased in popularity as a result of its ability to link practical conclusions and relevance to real-world organizational difficulties. AL has proven to be very effective in developing problem-solving abilities, teamwork, leadership and organizational growth across a wide range of industries in various countries. Although AL is becoming more popular, there is little study on it, and there have been calls for empirical educations that look into it more thoroughly [38]. Around the world, the number of enterprises using AL is steadily expanding. Companies use action learning as a tool for management and organizational development to gain competitive advantages [39]. The process for organizational support in action learning is shown in figure 7 .

\subsection{How Action Learning Promotes Organizational Development?}

Revans [17] was the first to advocate for the use of action learning to resolve organisational challenges, most notably by utilizing questions and inquiry with peers to advance coal mine productivity and safety, reduce nurse turnover and improve health recovery rates. Individual growth and professional practise have gotten a lot of attention in action learning over the last two decades. Here, the pendulum almost appears to swing the other way, with either little regard for overall organisation performance or an underlying belief that better service delivery will necessarily result from this individual improvement. Action learning has seen a revival in the field of learning and development in British public organizations this century [40]. With a few notable exceptions, investment has primarily concentrated on individual growth potential, particularly in the deployment of action learning for leadership and management development programmes. It's difficult to argue that action learning has any value in the public sector, especially when public funds are being spent and no tangible effects can be seen in people's lives [41]. Individuals and groups can benefit greatly from action learning, which can also aid in the development of 
organizational learning. Specifically, it can achieve the following:

- Improve your teamwork and collaboration abilities.

- Assist participants in developing mutually fruitful and respectful relationships with coworkers.

- Improve your problem-solving and decision-making abilities.

- Assist participants in applying research, theory, and management concepts to real-world organisational problems.

- Improve your critical and analytical thinking skills.

- Position investigation is at the heart of organisational behaviour.

- Improve participants' capability to reproduce on and acquire from their personal and group experiences.

- Develop individuals' knowledge of how their behaviour, attitude, and assumptions influence their decisionmaking.

- Create an immediate benefit solution to an organisational difficulty.

- Increase participants' skill and confidence in discussing other organisational challenges in their dayto-day working environments.

- Contribute to talent development and succession planning by assisting in the preparation of high-potential applicants for promotion.

- Give set participants the ability to apply action learning to other difficulties in their professional life.

\subsection{Case Studies of Action Learning Theory in Various Organizations}

\section{Working as a Team and Building Trust}

\section{Background of Case Study}

Trust between the top management team is critical in the ever-changing, highly competitive aerospace business. We used Action Learning (AL) to establish trust while working alongside an existing leadership programme.

\section{Approach}

The strategy began with a team-wide event aimed at fostering trust. The leadership was then divided into three AL Sets comprised of a diverse range of personalities. Before the Sets convened, the facilitator performed a coaching session with each participant to assist identify the important 'trust' concerns for them to work on. Each Set then met three times over the course of nine months. Two persons presented in each short and concentrated session, which was tailored to accommodate the leaders' busy schedules. The intervention culminated with a one-on-one coaching session for each participant to reflect on their particular learning and next steps.

\section{Result}

Each participant got new insights, selfawareness, and understanding of how to interact to others and develop trust in the context in which they work. The teams are now much more cohesive as a whole. They shifted away from their siloed approach to working and thinking, realized they were dealing with comparable difficulties, and were able to forge better bonds. There was a far higher desire to be vulnerable, which aided in better teamwork. The use of Action Learning was so beneficial that the majority of participants decided to form new AL groups. These were started with a single session and began self-facilitating after that. Working in this manner had the effect of making them want to do it again. The company's leadership development programmes now include Action Learning and Coaching as a mandatory component.

\section{Changing the Culture to Support Organizational Growth}

\section{Background of Case Study}

The University of Salford implemented an organisational development programme engaging approximately 360 academic and professional service workers to increase performance and generate a culture shift. To transmit the learning from the workshops to the workplace, they used Action Learning (AL). 


\section{Approach}

We collaborated with the institution to include Action Learning into the leadership workshop programme. An internal group of 13 facilitators was trained. We also offered suggestions on how to introduce and use AL. Following the leadership seminars, all participants were given internally-facilitated Action Learning Sets to help them address difficulties they encountered while working to establish a high-performance culture. We provided new facilitators with a series of CPD (Continuing Professional Development) courses after the Sets were up and running.

\section{Results}

Over 160 people offered to be a part of one of the 26 AL Sets. It served as a conduit for other leaders, forming internal networks, providing support, and assisting in the embedding of leadership material. Our customer experienced substantially stronger networks, with leaders realizing they shared a lot more in common than they thought. Each member acquired confidence and gained the ability to see challenges in a more educated and positive way. Furthermore, the teams became more proactive, energetic, and structured in their approach as a result of improved communication.

\section{Developing Leaders in the Social Enterprise Sector}

\section{Background of Case Study}

The School for Social Entrepreneurs (SSE) offers year-long programmes and courses to aspiring and experienced social entrepreneurs. All of their programmes are built around Action Learning (AL), which allows entrepreneurs to learn by sharing issues that arise in running their businesses and listening to others address their challenges.

\section{Approach}

Students study the principles, process and skills of action learning in introductory sessions. Then, either electronically or in person, we facilitate full or half-day Sets.

\section{Result}

AL acts as a sounding board for entrepreneurs, allowing them to try out new ideas and communicate with others, thereby minimizing isolation. It assists them in bringing ideas to life, maintaining momentum, and getting to the heart of what's going on, as well as developing their confidence and networks - as well as the skills, mentality, and behaviours needed to expand their social enterprises. After completing their programmes, many people join our Open Learning Groups because they value the connections, challenges, and support they get.

\subsection{Action Learning and Organizational Development: Challenges and Threats}

Because the relationship between theory and practise in action learning is inverted when compared to more traditional learning techniques, it has the potential to be extremely challenging of the hierarchical assumptions that dominate most organizations mindsets. Rather than being taught before to experience, theory is produced via reflection and conversation to explain and illuminate experience in action learning. Even the problems that people bring to action learning groups may be presenting worries, implying deeper issues that will only be exposed as part of the ongoing conversation with other members of the set. Thus, the power relationship of the learning scenario fundamentally shifts [42]. None are fully responsible for the facilitator or the organisation of the set member. The responsibility for what is taught stays largely with the individual student compared with traditional and formal learning approaches. Therefore, not unexpectedly, Boshyk [43], said that action learning was a possible threat to the interests of power and endangered uncertainty by revealing the organization's weaknesses.

Yet in practise this potential is limited by the continuous emphasis on individual personal and professional growth and on selfemployment difficulties. Why is that happening? In the atmosphere of intensive performance management, strict aims and continuous organisational and personal trouble, action learning experiences provide a place of relaxation in Pedler \& Attwood, [44] noted on the need for self and survival. Rigg, 
[45] suggested that the efforts to deflect individual member objectives on an organisational level are not prevalent. Donnenberg \& De Loo [46] proposed that many practitioners who find it too challenging just sidestep the question of the contribution of action learning to the organisational growth completely. De Loo, [47] taken up the framework of the organisation which had previously developed and which was assumed to have remained and necessary, claiming that action training concentrates far too much on required organizations in which everyone is assumed to inherently motivated for the achievement of organisational objectives - an overemphasis on how they are to behave and work [48]. As action learning therefore makes a difference, the result appeared solely to be a summation of the pieces or aggregation [49].

Development of the organization is also at stake. Although it was recently sued that the United Kingdom public sector had 'completely embraced' organizational development, recent healthcare research suggests that it had been interpreted and used: quick, demonstrable short-term results as a set of apparatuses and methods for development and executing change. This goes back to earlier criticisms that organisational development has been sanitized, supporters of the status quo and the application of recipes, the guardian of weaker organisational ideals, the social organizer and the misery tale [50]. There is also the issue of how organisational development is positioned inside organizations. In many organizations, it appears as part of this representation function at board level that the Human Resource or Personal Management functions were colonized. It has long been recognized that human resources have chosen a conformist position in innovation, while organisational development originally reflected a more deviant role in innovation [51].

The objective posture and the positivist accounts that consider organizations as actual objects and practises may be easily defined and quantified at the base of these issues for both actions and organisational growth [52]. Specifically, those connected to emotion and politics, which may be 'complicated and often overpowering,' may not be taken into account by organisational growth and action learning. In this regard, emotional and cognitive organisational life is co-created and organisation is understood as a transient consequence of interaction [53]. The focus is more on the organisation process than on organizations. This social-constructivist perception discards the possibility of a large narrative for a socially constructed reality, with its context and culture influencing and influencing the actors on stage and in which coalitions and powerful players constantly reform and negotiate the global view [54]. The organizations are therefore, not only lucid, prearranged and constant. The organisational reality is influenced by and continually changing talks and dialogues among the people within it. From this point of view, organizations are communities of meaning, nourished and maintained by patterns of interaction and communication and influenced by strong relationships and feelings of individuals [55].

\section{Discussion}

Proven in a powerful and effective form of organizational management in research, action learning is based on the theory of real-world work environments, rather than the management's acquisition of knowledge to increase their influence as a transformative leader. It is based on the idea that you have to live and learn. After that, they struggle to help them get back to work. Action learning is a procedure in which contributors work and learn simultaneously by solving real-world problems and producing real-world results [56]. Managers not only acquire formal knowledge, but also improve their skills through behavioral, practical example reflection. Learners are faced with real-world situations that serve as a starting point for acquiring skills. Participants learn from experience and remain motivated because the learning process is related to real work [57]. Perceptive but fearful people may regard action learning as so potent that they will not allow its implementation in their companies due to anticipated hazards to the organisation and their careers. The fear is that exposing the organization's shortcomings and impediments to improvement will shake everyone's confidence. This is a normal aspect of the procedure. Action learning is concerned with 
managing risk and uncertainty, but not with the negative features of harsh criticism and buck passing that are frequently connected with them. It focuses on managing risks and uncertainties, as well as learning from them for the benefit of the organization's stakeholders. Many people are learning that there are no risk-free treatments for their organisational ills as the West's recession deepens and the uncertainties and risks of simply living become painfully obvious [58]. As a result, they're looking for risky organisational learning and adaptation approaches that are also creative, motivating, and cost-effective. Action learning satisfies these criteria, but it will require significant organisational heft to get it off the ground and sustain itself as a management and thinking style appropriate for stormy times. One of the few positive aspects of the current economic and social downturn is that it is causing organisational upheavals. Because this is the only circumstance under which a truly radical rethinking of an organization's means and purposes can be conducted and the results applied systematically and quickly, it bodes well for action learning, which flourishes in crisis situations.

\section{Main Findings of the Study}

By reviewing the review of literature about the action learning and organizational development following important points have been revealed:

\section{A Methodical Strategy to Solve Problems and Dealing with Business Encounters}

- By predicting change and building internal procedures, Action learning theory advances an organization's preparation by actively responding to revolution.

- Action learning theory and models are extremely systematic and utilize a step-by-step methodology to support organisational development specialists in developing and implementing interventions aimed at improving a company's competitiveness and financial status.
- Action learning theory contemplates all the problems holistically and it also confirms that the matters are addressed actively with effective resolutions.

(ii) Assists in Investigation of Problems and Development of Appropriate Involvements

- The goal of action earning is to turn information into action.

- They help to identify the requirements of customers and current challenges, develop a contract to identify key performances and the work relation, collect data and identify gaps and causes, analyse data for priority setting and draught an action plan, decide on appropriate interventions and prepare an action plan.

- Implementation of short- and longterm change programmes that are successful.

(iii) Promotes a Culture of Learning

- Strategic planning, change management, decision-making and problem-solving, communication and organisational restructuring, leadership development, and the execution of process improvement projects may all benefit from the knowledge gained during the process.

- Provides optimum strategic options for dealing with a problem at hand or numerous organisational concerns; fosters a greater awareness of organisational functioning and challenges.

(iv) Senior Leaders and Stakeholders Play a Crucial Role

- Change agents are who as process specialists, effectively take command of the entire process, provide feedback, and communicate effectively with key stakeholders at all levels throughout the action learning process.

- Because change implementation goals cannot be reached without their approval and engagement, they include top management specialists as well as stakeholders in the process.

\section{(v) Easier Learning by Collaboration}

- The change agent collaborates with the client to identify issues, prioritize them, devise ways or procedures for 
finding the true cause of the problems, and design successful strategies that provide realistic and practical solutions for dealing with the difficulties.

- Aids in the development of mutual trust and reliance, both of which are essential for the success of any organisation.

- Aids in the rebuilding of organisational culture and the inclusion of employees in the entire transformation process, which would not have been feasible if an authoritarian leadership style had been used.

\section{(vi) Efforts to improve performance in} all areas

- The action learning theory and models take holistic approaches to discovering areas for improvement in all parts of an organization's operation and longterm performance.

- The process contributes to long-term improvements in performance from all perspectives by building a learning environment, better enabling knowledge and skill transfer, and taking a methodical approach to organisational transformation.

- Instead, than focusing on the separate subsystems of an organisation in isolation, Action Research takes a holistic approach to the organisation. This aids leaders in seeing the big picture and putting a roadmap of action or strategies in place to boost organisational performance and productivity.

\section{Limitations of Action Learning Theory \\ (i) Inadequate Assistance \\ Management}

The significant limitations of the action learning programme have been highlighted as the insufficient support or involvement of sponsors, top management or action learning managers participants. Jennings, [59] has found that managers are often not willing to provide information in the fields of action learning, arguing that they are too busy in the process in a comparative study of three approaches that include simulation, case studies and action learning. In their case study of Whitbread Restaurants' Beefeater locations, Hudspith \& Ingram [60]suggested that future challenges include inspiring and engaging key people in the firm to promote this form of learning. Many managers in a case study of a Dutch municipality did not want to be bothered with implementation and seemed solely concerned with meeting production targets.

\section{(ii) Issues with Time Commitment}

The majority of the action learning programmes documented in the literature lasted for a long time. Action learning procedures were found to be time consuming in general in studies for a variety of reasons. According to Jennings [59], it took a long time to establish partner ties for consulting tasks. The action learning process is typically thought to be time demanding.

\section{(iii) Insufficient Learning Resources Materials}

Two case studies were done, one from the Korean government and the other from the Walt Disney company. There is insufficient learning or reference resources like textbooks or manuals in the Senior Service Candidate Development Program of the Korean Central Government.

\section{Conclusion}

Action learning is a process of continuous learning and reflection, with the purpose of doing things well. It is a process of organizational reform and the liberation of human vision within the organization. The process is based on addressing one or more key organizational problems and analyzing their dynamics in real time; implement suggestions and solutions from constructive criticism from colleagues; monitor the results; and take responsibility for these actions, learn from the results to improve the future. Solve problems and take advantage of opportunities. In theory, this hardly differs from the logical procedures of any rational person trying to solve organizational problems. But organizations rarely act rationally. Therefore, it is a very powerful organizational tool to 
reform the work system and later reaffirm organizational objectives. This review study indicated that action learning theory improves the self-efficacy, cooperation between the organizational members and problem-solving abilities. The action learning models presented in this study are integration of action learning to improve the efficiency of the organizational system.

\section{Future Research}

More research should be done on the application of action learning theory for organizational development as very few studies have been found on the effectiveness of action learning theory on the organizational development in this literature review study.

\section{Declarations}

\section{Authors Contribution}

All authors contributed equally in this study.

\section{Conflict of Interest}

The author/s declared no conflict of interest.

\section{Funding}

No funding source received by this study.

\section{Data Availability}

No data is available for this study.

\section{References}

[1] Brook, Cheryl, and Mike Pedler. "Action learning in academic management education: A state of the field review." The International Journal of Management Education 18, no. 3 (2020): 100415 .

https://doi.org/10.1016/j.ijme.2020.10041 5

[2] Masango-Muzindutsi, Zandile, Lyn Haskins, Aurene Wilford, and Christiane Horwood. "Using an action learning methodology to develop skills of health managers: experiences from KwaZuluNatal, South Africa." BMC health services research 18, no. 1 (2018): 1-9. https://doi.org/10.1186/s12913-018-36936.

[3] Abramovich, S., Grinshpan, A. Z., \& Milligan, D. L. (2019). Teaching mathematics through concept motivation and action learning. Education Research
International, 2019. https://doi.org/10.1155/2019/3745406

[4] Revans, Reg. ABC of action learning. Routledge, 2017. https://doi.org/10.4324/9781315263533

[5] Skipton Leonard, H., and Fred Lang. "Leadership development via action learning." Advances in Developing Human Resources 12, no. 2 (2010): 225240.

[6] Cauwelier, P. (2019). Building highperformance teams through action learning. Action learning: research and practice, 16(1), 68-76. https://doi.org/10.1080/14767333.2019.15 62693

[7] Laitinen, Ilpo, Tony Kinder, and Jari Stenvall. "Co-design and action learning in local public services." Journal of Adult and Continuing Education 24, no. 1 (2018): 58-80.

[8] Choonara, S., J. Goudge, N. Nxumalo, and J. Eyles. "Significance of informal (onthe-job) learning and leadership development in health systems: lessons from a district finance team in South Africa." BMJ global health 2, no. 1 (2017): e000138. http://dx.doi.org/10.1136/bmjgh-2016000138

[9] Freedman, Arthur M. "Using action learning for organization development and change." Handbook for Strategic HRSection 6: Change Management (2015).

[10]Edmonstone, John, Aileen Lawless, and Mike Pedler. "Leadership development, wicked problems and action learning: provocations to a debate." Action Learning: research and practice 16 , no. 1 (2019):

37-51. https://doi.org/10.1080/14767333.2019.15 68967

[11] Schiller, Ulene, Penny Jaffray, Tamerin Ridley, and Cuzette Du Plessis. "Facilitating a participatory action learning action research process in a higher educational context." Action Research 19, no. 2 (2021): 301-317. http://dx.doi.org/10.1177/1476750318776 715

[12] MINGKHWAN, Chalita, and Siwanit Autthawuttikul. "development of action learning activities in classroom to enhance web design abilities for online training of undergraduate students faculty of education Silpakorn university." $\mathrm{PhD}$ diss., Silpakorn University, 2021.

[13]Casey, David, and David Pearce, eds. More Than Management 
Development: Action Learning at General Electric Company. Routledge, 2018.

[14]Pedler, M., and M. Attwood. "Do action learning sets generate "Social capital'." In 2nd International Action Learning Conference, Henley Business School, March. 2010.

[15]Raelin, Joseph A., and David Coghlan. "Developing managers as learners and researchers: Using action learning and action research." Journal of Management Education 30, no. 5 (2006): 670-689.

[16]Milani, Alfredo, Rajdeep Niyogi, and Giulio Biondi. "Neural network based approach for learning planning action models." In International Conference on Computational Science and Its Applications, pp. 526-537. Springer, Cham, 2019. https://doi.org/10.1007/978-3-03024311-1_38.

[17] Revans, Reginald W. "What is action learning?" Journal of management development (1982). Vol.1 No.3, pp.6475. https://doi.org/10.1108/eb051529

[18] Chandak, Yash, Georgios Theocharous, James Kostas, Scott Jordan, and Philip Thomas. "Learning action representations for reinforcement learning." In International Conference on Machine Learning, pp. 941-950. PMLR, 2019.

[19] Posch, Peter. "Action research-conceptual distinctions and confronting the theorypractice divide in Lesson and Learning Studies." Educational Action Research 27, no. 4 (2019): 496-510. https://doi.org/10.1080/09650792.2018.15 02676

[20]Zuber-Skerritt, Ortrun. "Participatory action learning and action research (PALAR) for community engagement: A theoretical framework." Educational research for social change 4, no. 1 (2015): 5-25.

[21]Raelin, Joe. "Does action learning promote collaborative leadership?" Academy of Management Learning \& Education 5, no. 2 (2006): 152-168. https://doi.org/10.5465/amle.2006.212537 80

[22] Bourner, Tom, Cheryl Brook, and Mike Pedler. "The Nurses Memorandum of 1938: a first step in the development of action learning?" Action Learning: Research and Practice 15, no. 1 (2018): 28-37.

https://doi.org/10.1080/14767333.2017.14 08568
[23] Whitehead, Jack. "Contributing to moving action research to activism with living theory research." The Canadian Journal of Action Research 20, no. 3 (2020): 55-73. http://insight.cumbria.ac.uk/id/eprint/5679

24] Stringer, Ernest T., and Alfredo Ortiz Aragón. Action research. Sage publications, 2020.

[25]Yeo, Roland K., and Michael J. Marquardt. "Complex problem solving through action learning: implications for human resource development." International Journal of Human Resources Development and Management 12, no. 4 (2012): 258-273. https://doi.org/10.1504/IJHRDM.2012.04 9782

[26] Marquardt, Michael, and Roland K. Yeo. "11. Organizational Change and Learning." In Breakthrough Problem Solving with Action Learning, pp. 187198. Stanford University Press, 2020. https://doi.org/10.1515/9780804781862014

[27] Wessels, Elsabé, and Lesley Wood. "Fostering teachers' experiences of wellbeing: A participatory action learning and action research approach." South African Journal of Education 39, no. 1 (2019). https://doi.org/10.15700/saje.v39n1a1619

[28]McGill, Ian, and Liz Beaty. Action Learning: a guide for professional, management \& educational development. Psychology Press, 2001.

[29] Abokhodair, Eiman S. "Action Learning as an Approach for Developing Leaders, Solving Problems, and Building Successful Teams." In Community Engagement in Higher Education, pp. 303-316. Sense Publishers, Rotterdam, 2015. https://doi.org/10.1007/978-946300-007-9_18

[30]Lee, Hye-Jin, and Kyeung Jang. "The Convergence Effects of Oral Health Education Class Applying Action Learning on Communication Ability and Problem-Solving Ability." Journal of Convergence for Information Technology 9, no. 11 (2019): 212-217. https://doi.org/10.22156/CS4SMB.2019.9. 11.212

[31] Kim, Soung-Hyun, and JaeSung Park. "A Study on Intention to Solve the Problem via the Prior Experience of Creativity Programs based on the Action Learning Methodology." Journal of Digital Convergence 19, no. 6 (2021): 73-83. https://doi.org/10.14400/JDC.2021.19.6.0 73 
[32] Gregory, Michael. "Accrediting work $\square$ based learning: action learning-a model for empowerment." Journal of Management Development (1994). Vol. 13 No. 4, pp. 4152. https://doi.org/10.1108/026217194100 57069

[33] Lewin, Kurt. "Action research and minority problems." Journal of social issues 2, no. 4 (1946): 34-46.

[34] Kolb DA. Experience as the source of learning and development. Upper Sadle River: Prentice Hall. 1984.

[35]Paton, Graham. "A systemic action learning cycle as the key element of an ongoing spiral of analyses." Systemic Practice and Action Research 14, no. 1 (2001):

95-111. https://doi.org/10.1023/A:1009539811800

[36] Watkins, Karen E., and Victoria J. Marsick. Sculpting the learning organization: Lessons in the art and science of systemic change. Jossey-Bass Inc., 350 Sansome Street, San Francisco, CA 94104-1310, 1993.

[37] O'neil, Judy, and Victoria J. Marsick. Understanding action learning. AMACOM Div American Mgmt Assn, 2007.

[38]Pedler, Mike, ed. Action learning in practice. Gower Publishing, Ltd., 2011.

[39] Cho, Yonjoo, and Toby Egan. "Organizational support for action learning in South Korean organizations." Human Resource Development Quarterly 24, no. 2 (2013): 185-213. https://doi.org/10.1002/hrdq.21154

[40] Yeadon-Lee, Annie. "Reflective vicarious learning (RVL) as an enhancement for action learning." Journal of Management Development (2018), Vol. 37 No. 4, pp. 363-371. https://doi.org/10.1108/JMD-112017-0348

[41] Abramovich, Sergei, Arcadii Z. Grinshpan, and David L. Milligan. "Teaching mathematics through concept motivation and action learning." Education Research International (2019). https://doi.org/10.1155/2019/3745406

[42] Ballantine, M. "David Sutton fellowship report." Action Learning: Research and Practice 8, no. 2 (2003): 93-102.

[43] Boshyk, Yury. "Action Learning in the business world: past, present, and future." In Action learning and its applications, pp. 68-98. Palgrave Macmillan, London, 2010 . https://doi.org/10.1057/9780230250741 5

[44] $\bar{P}$ edler, Mike, and Margaret Attwood. "Action Learning and Social Capital." In Action Learning in Practice, pp. 341352. Routledge, 2016.

[45]Rigg, Clare. "Action learning for organizational and systemic development: towards a 'both-and 'understanding of 'I'and 'we'." Action Learning: Research and Practice 5, no. 2 (2008): 105-116. https://doi.org/10.1080/147673308021856 16

[46] Jacobs, Gaby C. "The development of critical being? Reflection and reflexivity in an action learning programme for health promotion practitioners in the Netherlands." Action Learning: Research and Practice 5, no. 3 (2008): 221-235. https://doi.org/10.1080/147673308024613 06

[47]De Loo, Ivo. "The troublesome relationship between action learning and organizational growth." Journal of workplace learning (2002), Vol. 14 No. 6, pp.

245255. https://doi.org/10.1108/13665620210 441207

[48]Flores, Walter. "How can evidence bolster citizen action? learning and adapting for accountable public health in Guatemala." Accountability Research Center, Accountability Note 2 (2018).

[49] Smith, Sue, and Laurie Smith. "Assessing the value of action learning for social enterprises and charities." Action Learning: Research and Practice 14, no. 3 (2017): 230-242. https://doi.org/10.1080/14767333.2017.12 88081

[50] Schiller, Ulene, Penny Jaffray, Tamerin Ridley, and Cuzette Du Plessis. "Facilitating a participatory action learning action research process in a higher educational context." Action Research 19, no. 2 (2021): 301-317.

[51]Scott, Kimberly S. "An integrative framework for problem-based learning and action learning: Promoting evidencebased design and evaluation in leadership development." Human Resource Development Review 16, no. 1 (2017): 334.

[52]Babińska, Danuta. "Applying action learning in the development of business students' intercultural competences." European Journal of CrossCultural Competence and Management 5, no. 3 (2021): 287-300. 
https://doi.org/10.1504/EJCCM.2021.116 877

[53] Burke, Robert. "Anticipatory Action Learning, Leadership, Strategy and Foresight: Creating a Successful Future While Enhancing Results Today." Journal of Futures Studies 25, no. 3 (2021): 85-92. https://doi.org/10.6531/JFS.202003_24(3). 0002

[54] Robertson, Jane, and Diane Bell. "Safe or unsafe? The paradox of action learning." Action Learning: Research and Practice 14, no. 2 (2017): 185-196. https://doi.org/10.1080/14767333.2017.13 10691

[55]Babalola, Olusegun. "Protean Career Orientation and Work Outcomes: An Action Theory and Social Exchange Theory Perspective." PhD diss., 2021. https://hdl.handle.net/10657/7966

[56] Lehmann, Uta, and Lucy Gilson. "Action learning for health system governance: the reward and challenge of coproduction." Health policy and planning 30, no. 8 (2015): 957-963. https://doi.org/10.1093/heapol/czu097

[57] Imperiale, Angelo Jonas, and Frank Vanclay. "Experiencing local community resilience in action: Learning from postdisaster communities." Journal of Rural Studies $47 \quad$ (2016): 204-219. https://doi.org/10.1016/j.jrurstud.2016.08. 002

[58] Greenleaf C, Valencia S. Missing in action: Learning from texts in subjectmatter classrooms. Adolescent literacies: A handbook of practice-based research. 2017:235-56.

[59] Jennings, David. "Strategic management: an evaluation of the use of three learning methods." Journal of Management Development (2002). Vol. 21 No. 9, pp. 655-

665. https://doi.org/10.1108/02621710210 441658

[60]Hudspith, Debby, and Hadyn Ingram. "Delivering management development through action learning." International Journal of Contemporary Hospitality Management (2002), Vol. 14 No. 7, pp. 368-

374. https://doi.org/10.1108/09596110210 440675

\section{Sources of funding for research presented in a scientific article or scientific article itself}

Report potential sources of funding if there is any

\section{Creative Commons Attribution License 4.0 (Attribution 4.0 International, CC BY 4.0)}

This article is published under the terms of the Creative Commons Attribution License 4.0 https://creativecommons.org/licenses/by/4.0/d eed.en_US 